\title{
Long term disease-free survival and $T$ cell and antibody responses in women with high-risk Her2+ breast cancer following vaccination against Her2
}

\author{
Michael A Morse*1, Amy Hobeika2 ${ }^{2}$ Takuya Osada2 ${ }^{2}$, Donna Niedzwiecki³ \\ Paul Kelly Marcom ${ }^{4}$, Kimberly L Blackwell ${ }^{5}$, Carey Anders ${ }^{1}$, Gayathri R Devi ${ }^{2}$, \\ H Kim Lyerly ${ }^{2,6}$ and Timothy M Clay ${ }^{7}$
}

\begin{abstract}
Address: ${ }^{1}$ Department of Medicine, Division of Medical Oncology, Duke University Medical Center, Box 3233, Durham, NC 27710, USA, ${ }^{2}$ Department of Surgery, Duke University Medical Center, Box 2606, Durham, NC 27710, USA, ${ }^{3}$ Department of Biostatistics \& Bioinformatics, Duke University Medical Center Box 3958, Durham, NC 27710, USA, ${ }^{4}$ Department of Medicine, Division of Medical Oncology, Duke University Medical Center, Box 3147, Durham, NC 27710, USA, ${ }^{5}$ Department of Medicine, Division of Medical Oncology, Duke University Medical Center, Box 3893, Durham, NC 27710, USA, 'Duke Comprehensive Cancer Center (DCCC), Duke University Medical Center, 6th Floor Hock Plaza, Durham, NC 27710, USA and ${ }^{7}$ Department of Surgery, Division of Experimental Surgery, Duke University Medical Center, Box 2606, Durham, NC 27710, USAfigr
\end{abstract}

Email: Michael A Morse* - morse004@mc.duke.edu; Amy Hobeika - amy.hobeika@duke.edu; Takuya Osada - osada001@mc.duke.edu; Donna Niedzwiecki - niedz001@mc.duke.edu; Paul Kelly Marcom - marco001@mc.duke.edu; Kimberly L Blackwell - black034@mc.duke.edu; Carey Anders - ander118@notes.duke.edu; Gayathri R Devi - gayathri.devi@duke.edu; H Kim Lyerly - lyerl001@mc.duke.edu; Timothy M Clay - clay0017@mc.duke.edu

* Corresponding author

Published: 6 September 2007

Journal of Translational Medicine 2007, 5:42 doi:10.1 186/1479-5876-5-42
Received: 22 May 2007

Accepted: 6 September 2007

This article is available from: http://www.translational-medicine.com/content/5/1/42

(C) 2007 Morse et al; licensee BioMed Central Ltd.

This is an Open Access article distributed under the terms of the Creative Commons Attribution License (http://creativecommons.org/licenses/by/2.0), which permits unrestricted use, distribution, and reproduction in any medium, provided the original work is properly cited.

\begin{abstract}
Background: The HER2-inhibiting antibody trastuzumab, in combination with chemotherapy, significantly improves survival of women with resected, HER2-overexpressing breast cancers, but is associated with toxicities including a risk of cardiomyopathy. Additionally, the beneficial effect of trastuzumab is expected to decrease once the drug is discontinued. We proposed to address these concerns by using cancer vaccines to stimulate HER2 intracellular domain (ICD)-specific $T$ cell and antibody responses.
\end{abstract}

Methods: Subjects with stage II $(\geq 6+L N)$, III, or stage IV breast cancerwith $>50 \%$ HER2 overexpressing tumor cells who were disease-free after surgery and adjuvant therapy were eligible. Vaccines consisted of immature, cultured DC $(n=3)$, mature cultured DC $(n=3)$, or mature Flt3ligand mobilized peripheral blood DC $(n=1)$ loaded with ICD, or tetanus toxoid, keyhole limpet hemocyanin or CMV peptide as controls, and were administered intradermally/subcutaneously four times at 3 week intervals. ICD-specific $T$ cell and antibody responses were measured. Cardiac function was determined by MUGA or ECHO; long term disease status was obtained from patient contact.

Results: All seven patients successfully underwent DC generation and five received all 4 immunizations. There were no toxicities greater than grade I or ejection fraction decrements below normal. Delayed-type hypersensitivity (DTH) reactions at the injection site occurred in 6/7 patients and HER2 specificity was detected by cytokine flow cytometry or ELISPOT in 5 patients. At more than 5 years of follow-up, 6/7 had detectable anti-ICD antibodies. One patient 
experienced a pulmonary recurrence at 4 years from their study immunizations. This recurrence was resected and they are without evidence of disease. All patients are alive and disease-free at 4.6-6.7 years of follow-up.

Conclusion: Although this was a small pilot study, the well-tolerated nature of the vaccines, the lack of cardiac toxicity, significant immunogenicity, and a 100\% 4.5-year survival rate suggest that vaccination with HER2 ICD protein-containing DC is appropriate for further study in this population.

Trial Registration: ClinicalTrials.gov NCT00005956

\section{Background}

HER2 overexpression occurs in $20-30 \%$ of breast cancers and is associated with more aggressive tumors and poorer overall survival (OS) in those with resected disease [1]. Recently, the benefit of combining the anti-HER2 antibody trastuzumab with chemotherapy in reducing the rate of recurrence mortality of resected, HER2 overexpressing breast cancer was established [2]. Although the addition of trastuzumab significantly improved survival in these studies, it has been associated with toxicities including cardiac dysfunction and, less frequently, interstitial pneumonitis. Furthermore, the effect of trastuzumab is only expected to persist while it remains at clinically relevant concentrations. For these reasons, we sought to study the role of an alternative strategy to target the intracellular domain (ICD) of HER2 via stimulation of HER2-specific $\mathrm{T}$ cell and antibody responses using cancer vaccines.

More than a dozen phase I and phase II studies have been conducted in breast cancer patients with cancer vaccines [3], that have included proteins, peptides, modified tumor cells, and dendritic cells loaded with breast tumor antigens. In these studies, HER2 has been demonstrated to be immunogenic [4-13]. For example, in a study of 31 patients with stage III or IV HER2+ breast cancer who received 6 monthly vaccinations consisting of a T helper epitope from HER2 protein plus GM-CSF, 92\% of the patients demonstrated HER2 immunity as measured by T cell proliferation. Importantly, immunity lasted for at least 1 year in 38\% of responding patients [7]. Recently, a vaccine consisting of a peptide derived from the extracellular domain of HER2 (E75 peptide (HER2 369-377)) mixed with GM-CSF was administered at various doses and schedules to patients with resected node positive and node negative breast cancer. All patients demonstrated in vivo DTH responses and in vitro immunologic responses following vaccination. The recurrence rate for the vaccinated patients was $5.6 \%$ compared to $14.8 \%$ for an observational group of patients at a median of 24 months $[12,13]$.

To improve upon the immunologic and clinical activity of HER2-directed vaccines, we chose dendritic cells (DC) as the platform for delivering HER2 antigen. DC are the most effective antigen presenting cell for activating CD8+ cytolytic $\mathrm{T}$ cells, CD4+ T cell help, and antibody responses [14]. Furthermore, most cancer vaccines require cross presentation of the administered antigen by DC [15]. We therefore hypothesized that vaccines based on DC loaded with tumor antigens would provide potent antitumor responses with low toxicity, precise specificity, and a sustained effect (due to immunologic memory). There are several possible sources of DC for immunotherapy strategies [16]; DC may be generated in vitro from monocytoid precursors or CD34+ progenitors [17]. DC may also be found circulating in the peripheral blood and their numbers may be markedly enhanced after administration of Flt3-ligand [18]. Because there is a debate over whether mature or immature DC are the preferred cell source for cancer vaccine strategies, we designed our study as a series of pilot experiments with one group of patients receiving immature DC, then the next mature DC, and finally, Flt3ligand mobilized DC. Because the efficacy of immunotherapy may be greatest in the setting of low burden of tumor when tumor-induced immune suppression is less likely, we tested DC-based immunization strategies in women with resected HER2-expressing breast cancer with a high risk of recurrence. We previously reported preliminary data for the immunization response in a subset of these patients [17]. We now report on long-term safety and survival of the entire group of women who received DC loaded with HER2 ICD protein fragment as vaccine therapy for high-risk breast cancer. In addition, we report on antibody responses detectable after more than 5 years of follow-up.

\section{Methods}

This phase I study was reviewed and approved by the Duke University Institutional Review Board in accordance with all federal, state and local requirements. Patients provided written informed consent prior to receiving any protocol therapy.

\section{Patients}

Patients were eligible if they had invasive (defined as stage II with at least 6 positive lymph nodes, stage III, or 
resected stage IV) HER2-overexpressing (2+ or $3+$ by immunohistochemistry (IHC) or FISH amplified) breast cancer, a group with a historically high $(30-50 \%$ or greater) risk of recurrence. In addition to having undergone a complete surgical resection, they were to have completed adjuvant therapy consisting of chemotherapy ( \pm trastuzumab) and/or radiotherapy at least 4 weeks prior to study entry, have normal cardiac function, no evidence of autoimmune disease, and be free of corticosteroids. Continuation of adjuvant hormonal therapy was permitted.

\section{Dendritic Cell Vaccine}

Patients underwent a 2-4 hour leukapheresis in order to obtain peripheral blood mononuclear cells (PBMCs) for generation of DC. Three-quarters of the pheresed PBMCs were utilized for DC and one-quarter was frozen for baseline immunologic study. The first DC product for each patient was generated and used fresh and the remainder were cryopreserved and thawed when needed for subsequent immunizations. The DC were generated ex vivo in one of three ways: The first three patients (Her2-I-01, Her2-I-02, and Her2-I-03) were immunized with immature DC generated from their PBMCs with GM-CSF and IL-4 over seven days, and loaded with the HER2 ICD protein $(500 \mu \mathrm{g})$ (generously provided by Corixa, Inc., Seattle, WA). Control immunizations consisted of similarly prepared DC loaded with tetanus toxoid (TT) 4 Lf and keyhole limpet hemocyanin (KLH) $200 \mu \mathrm{g}$. The next three patients (DC-ICD-MAT-01，DC-ICD-MAT-02，DC-ICDMAT-03) were immunized with DC generated from their PBMCs with GM-CSF and IL-4, loaded with the ICD of HER2 protein, the E75 extracellular domain (ECD) peptide, and then matured with CD40-ligand plus IFN $\gamma$. Control immunizations consisted of similarly prepared DC loaded with keyhole limpet hemocyanin (KLH) $200 \mu \mathrm{g}$, or CMV pp 65 peptide $500 \mu \mathrm{g}$. The third cohort was to utilize blood DC mobilized with FLT3-ligand, loaded with ICD protein overnight and then matured with GM-CSF, CD40ligand and IFN $\gamma$. Control immunizations consisted of similarly prepared DC loaded with tetanus toxoid (TT) 4 Lf, keyhole limpet hemocyanin (KLH) $200 \mu \mathrm{g}$, and CMV pp65 peptide $500 \mu \mathrm{g}$. A single patient (FL-DC-MAT-01) received that preparation, because at that point the ICD protein and FLT3-ligand became unavailable. Consequently, no further patients were enrolled on this trial. A total of 4 injections were to be given every 3 weeks as a combination of intradermal (100 microliters) and subcutaneous (900 microliters) injections. Patients were followed clinically with routine imaging requested approximately every 3 months to confirm patientreported disease status. MUGA scans or echocardiograms were recommended upon completion of the immunizations to monitor ejection fraction.

\section{Immunologic analysis}

DTH reactions

The clinical method for measuring immunologic immune responses consisted of measuring the longest diameter of induration and erythema at the injection site 48 hours after each immunization (reported as the delayed type hypersensitivity (DTH) reaction). In addition, prior to each immunization and at completion of the series of immunizations, patients received intradermal injections of $10 \mathrm{mcg}$ of ICD protein or Candida at 1:1000 dilution $(0.1 \mathrm{ml})$ to assess reactivity to the immunizing antigen compared with a control. Patients who received DC loaded with KLH also had DTH testing with 10 mcg KLH. The maximum diameter of erythema and induration was measured at 48 hours after the intradermal injection.

\section{ELISpot}

Peripheral blood mononuclear cells were analyzed for immunologic analysis as follows: Immulon-2 96-well flat bottom plates were coated with $50 \mu \mathrm{L} /$ well antihuman interferon- $\gamma$ (IFN- $\gamma$ ) monoclonal antibody (MoAb; M700A, Endogen, Perbio Science, HelsingboFrg, Sweden) in a coating buffer (1:500) and incubated for a minimum of 2 hours at room temperature or overnight at $4{ }^{\circ} \mathrm{C}$. The coated plates were washed 10 times with phosphate buffered saline (PBS), 0.1\% Tween 20, then blocked with fetal bovine serum (FBS)-containing medium for 30-60 minutes at $37^{\circ} \mathrm{C}, 5 \% \mathrm{CO}_{2}$. Effector cells were plated in quadruplicate in serial dilutions starting with $2 \times 10^{5}$ cells/well. Antigen was added to the wells and the plates were incubated for $48-50$ hours at $37^{\circ} \mathrm{C}, 5 \% \mathrm{CO}_{2}$, and then washed. Antihuman IFN- $\gamma$ biotinylated MoAb $50 \mu \mathrm{L} /$ well at $1: 500$ in $1 \%$ FBS/PBS was added and incubated at room temperature for 2 hours or $4^{\circ} \mathrm{C}$ overnight, and then washed. Alkaline phosphatase-strepavidin $50 \mu \mathrm{L} /$ well $(1: 200)$ in $1 \%$ FBS/PBS was added and incubated at room temperature for 2 hours, and then washed. BCIP/NBT (5bromo-4-chloro-3'-indolphosphate p-toluidine salt/ nitro-blue tetrazolium chloride) substrate (Vector Laboratories, Burlingame, CA) $50 \mu \mathrm{L} /$ well was added and incubated for 1 hour at room temperature in the dark, and then rinsed 3 times with deionized water. The membranes were dried overnight in the dark. Membranes were removed using sealing tape (Millipore, Bedford, MA) and were read by Zellnet Consulting, Inc, using the KS ELISA Automated Reader System with the KS ELISA 4.2 software (Carl Zeiss, Inc, Thornwood, NY).

\section{Cytokine Flow Cytometry}

Intracellular cytokine staining was performed by incubating 2-4 × $10^{6}$ PBMCs isolated pre-immunization and post immunizations for 5 hours at $37^{\circ} \mathrm{C}$ in the presence of anti-CD28 and media alone, ICD protein, KLH protein, and TT (Sigma-Aldrich, St. Louis, MO). Brefeldin A was added for the last 3 hours of incubation. The stimulated 
cells were washed with $1 \%$ bovine serum albumen/PBS, fixed with $1 \%$ paraformaldehyde, and permeabilized using FACS ${ }^{\mathrm{TM}}$ Permeabilizing Solution (Becton Dickinson, San Jose, CA). Permeabilized cells were then stained with anti-IFN- $\gamma$-FITC, anti-CD69-PE, anti-CD8-PerCP, and anti-CD4-APC for 30 minutes at room temperature. Cells were gated by forward and side scatter for lymphocytes and positively for CD8. CD69 is an activation marker. The percentage of CD69+/IFN- $\gamma+$ cells (ie, activated and cytokine producing) was then determined.

\section{HER2-ICD ELISA}

HER2-ICD protein was dissolved in PBS $(10 \mu \mathrm{g} / \mathrm{ml})$. High binding 96-well ELISA plates (Immulon 4HBX; ThermoLabsystems, Franklin, MA) were coated with HER2-ICD solution $(200 \mu \mathrm{l} /$ well $)$ for overnight at $4{ }^{\circ} \mathrm{C}$. After washing with $0.05 \%$ Tween 20 in PBS (PBS-T), $200 \mu$ l of $1 \%$ bovine serum albumin in PBS was added for blocking of the wells and incubated for 2 hours at room temperature. Serially diluted patients' sera $(200 \mu \mathrm{l} /$ well $)$ were added to the plates and incubated overnight at $4{ }^{\circ} \mathrm{C}$. Control serum from a normal donor was used as a negative control. Washed with PBS-T, and alkaline phosphatase-conjugated goat anti-human IgG (MP Biomedicals, Inc.; Aurora, Ohio) was put to the plates (1:5000 dilution in PBS) and incubated for 3 hours at $37^{\circ} \mathrm{C}$. Unbound conjugate was removed by washing with PBS-T, and $1 \mathrm{mg} / \mathrm{ml}$ solution of p-nitrophenyl phosphate in Tris buffer (Sigma, St. Louis, $\mathrm{MO})$ was added to the wells $(50 \mu \mathrm{l} /$ well $)$. Color development was stopped by adding $50 \mu \mathrm{l}$ of $3 \mathrm{~N} \mathrm{NaOH}$. Absorbance at $405 \mathrm{~nm}$ was measured.

\section{Statistical analysis}

Results were immunologic analyses were primarily descriptive. A Kaplan-Meier disease-free survival estimate and $95 \%$ confidence bounds was generated for the clinical data.

\section{Results \\ Patient Characteristics}

Seven women with a median age of 47 were enrolled onto the study (Table 1). Five patients had stage III and two had stage IV breast cancer. The median number of positive lymph nodes was 7 (range: 0-11). HER2 expression by IHC was high in all patients; specifically, $100 \%$ of the tumor cells in two patients, $80 \%$ in one patient, and all others were reported by the pathologist to be $\geq 2+$. Two patients had ER/PR negative tumors. Prior therapy included high-dose chemotherapy with peripheral blood stem cell transplantation, hormonal therapy, chemotherapy, and post-surgical radiotherapy, and in one case, a dendritic cell vaccine loaded with CEA mRNA. Two patients had received trastuzumab, one for 12 weeks and the other for 1 year prior to enrollment. Three of the women were receiving maintenance hormonal therapy.
All patients successfully underwent leukapheresis and generation of at least one DC product. Viability of cryopreserved DC was 70-98\%. The immature DC had the expected phenotype (CD83 low, CD86+HLA-DR+) and the matured DC expressed upregulated CD83 (range: 1698\% CD83+) among both fresh and cryopreserved DC. The matured DC preparations demonstrated IL-12 production. Specifically, within the DC of three patients analyzed (two in the cohort with monocyte derived and matured DC and the patient receiving Flt3-ligand mobilized and matured DC), intracellular IL-12 expression was demonstrated in $2-8 \%$ of the CD $83+$ cells, indicating an activated state.

\section{Immune Response}

We used as the primary indicator of immune response DTH reactions observed at the vaccine injection sites (Table 2). These DTH reactions to the ICD loaded vaccine (erythema and/or induration), ranging from no reaction up to105 $\mathrm{mm}$ in longest diameter, were observed at the injection site in all but the one patient who received only a single immunization with the DC. In four patients, the diameter of the induration/erythema increased from the first to a subsequent immunization, and in two patients the first immunization gave the greatest induration/erythema. We also examined reactivity to the antigens administered intradermally without dendritic cells before and after all immunizations. Among five patients who were analyzed, two had an increase in size in the diameter of erythema/induration at the intradermal injection site following the immunizations, one had a decrease in size, and two patients had no DTH reactivity to ICD. When responses to Candida were similarly analyzed, only one of five had an increase in the diameter of the DTH reaction, while four patients had a decrease following all the immunizations. This suggests that responses against the HER2 were likely specific and not due to a non-specific increase in DTH reactivity.

As further confirmation of the HER2 specificity of the immune response, we analyzed patient PBMC by ELISpot and intracellular cytokine staining. ELISpot analysis was performed on the PBMCs from each patient prior to vaccinations (pre), following vaccinations (post), and at long term follow up (up to 5 years following immunizations) (Table 2). We initially reported our results in three patients for immune response during the immunizations [19]. We now report results for all patients with longer follow-up (up to 5 years). As demonstrated in Table 2, 3 of 3 patients receiving immature $\mathrm{DC}$, and 2 of 3 receiving matured DC developed a positive or increased response to ICD protein as demonstrated by ELISpot results. Out of these 5 patients, 3 had an immune response to Her2-ICD up to 5 years following the DC vaccinations. Interestingly, these results indicate the Her2-ICD specific T cell response 
Table I: Patient characteristics $(n=7)$

\begin{tabular}{|c|c|c|c|c|c|c|}
\hline Patient & Age & Disease Stage & Number + Lymph Nodes & HER2 Status & Prior Treatment/s & Maintenance Hormones \\
\hline \multicolumn{7}{|c|}{ Vaccinations: immature DC (GM-CSF, IL-4) + HER2 ICD protein control DC loaded with KLH and tetanus toxoid } \\
\hline \#I & 38 & T3pN3 - IIIC & $>10$ & $\begin{array}{l}>80 \% \text { cells } \\
\text { overexpress by IHC }\end{array}$ & AC-Taxol; trastuzumab & Raloxifene (ER/PR+) \\
\hline$\# 2$ & 56 & TIcpN2MI - IV & 7 & $\begin{array}{l}100 \% \text { cells } \\
\text { overexpress by IHC }\end{array}$ & $\begin{array}{l}\text { Taxol; HDC + Auto } \\
\text { PBSCT DC-CEA vaccine }\end{array}$ & Tamoxifen (ER/PR+) \\
\hline \#3 & 57 & T3pN2 - IIIC & 7 & $3+$ & $\begin{array}{l}\text { doxorubicin HDC + Auto } \\
\text { PBSCT }\end{array}$ & None (ER/PR-) \\
\hline
\end{tabular}

\begin{tabular}{|c|c|c|c|c|c|c|}
\hline \multicolumn{7}{|c|}{$\begin{array}{l}\text { Vaccinations: Mature DC (GM-CSF, IL-4, CD40-ligand, IFN } \gamma \text { ) + HER2 ICD protein, E75 ECD peptide control DC loaded with KLH } \\
\text { and CMV peptide }\end{array}$} \\
\hline$\# 4$ & 47 & TIPN2 - IIIA & 8 & $3+$ & $\begin{array}{l}\text { AC; Taxotere; } \\
\text { Radiotherapy }\end{array}$ & None (ER/PR-) \\
\hline \#5 & 58 & T2pN3 - IIIC & II & $2+$ & FAC; Taxol; XRT & Tamoxifen (ER/PR+) \\
\hline \#6 & 38 & IV (liver) & 0 & High & $\begin{array}{l}\text { Taxotere; Trastuzumab } \\
\text { (prior to enrollment and } \\
\text { then continued on } \\
\text { maintenance }>4 \text { years); } \\
\text { FAC; Navelbine; RFA of } \\
\text { liver lesion }\end{array}$ & None (ER/PR-) \\
\hline
\end{tabular}

Vaccinations: DC (FLT3-ligand) + GM-CSF + CD40-ligand + IFN $\gamma+$ HER2 ICD protein control DC loaded with KLH, tetanus toxoid and CMV peptide

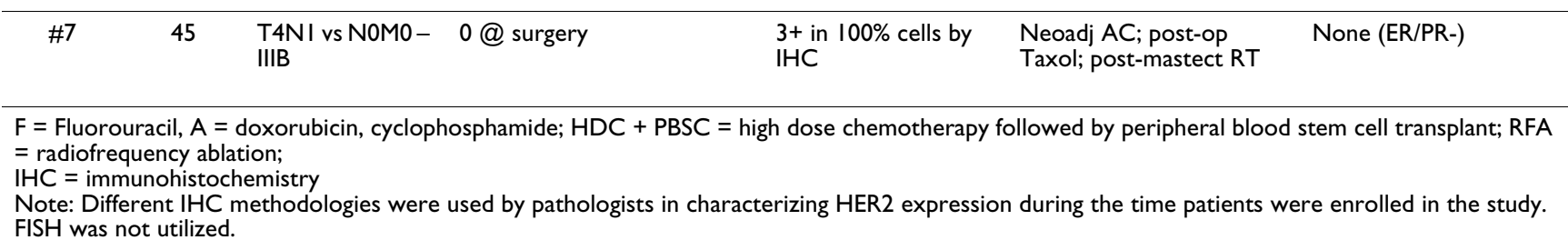

was not always greatest at the conclusion of the immunizations. Her2-I-01 and DC-ICD-MAT-03 also had Her2ECD specific responses up to 5 years following immunizations. The patient receiving FLT3-Ligand mobilized and matured DC did not activate ICD-specific T cells but had in increase in ECD specific T cells. In patient Her2-I-01, we confirmed that the Her2-ICD immune response occurred among both CD4 and CD8+ T cells by intracellular IFN $\gamma$ production (Figure 1).

Although $\mathrm{T}$ cell responses were the initial primary immune response measured, when the subjects were evaluated at more than 5 years of follow-up, we analyzed antibody responses specific for ICD by ELISA. As

Table 2: Longest DTH diameter at injection site of DC loaded with various antigens

\begin{tabular}{|c|c|c|c|c|c|c|c|c|}
\hline Patient & $\begin{array}{l}\text { Longest } \\
\text { diameter of } \\
\text { induration } \\
\text { at site of DC } \\
\text { loaded with } \\
\text { ICD (mm) }\end{array}$ & $\begin{array}{l}\text { Longest } \\
\text { diameter of } \\
\text { erythema at } \\
\text { site of DC } \\
\text { loaded with } \\
\text { ICD }(\mathrm{mm})\end{array}$ & $\begin{array}{l}\text { Longest } \\
\text { diameter of } \\
\text { induration } \\
\text { at site of DC } \\
\text { loaded with } \\
\text { TT (mm) }\end{array}$ & $\begin{array}{l}\text { Longest } \\
\text { diameter of } \\
\text { erythema at } \\
\text { site of DC } \\
\text { loaded with } \\
\text { TT (mm) }\end{array}$ & $\begin{array}{l}\text { Longest } \\
\text { diameter of } \\
\text { induration } \\
\text { at site of DC } \\
\text { loaded with } \\
\text { CMV (mm) }\end{array}$ & $\begin{array}{l}\text { Longest } \\
\text { diameter of } \\
\text { erythema at } \\
\text { site of DC } \\
\text { loaded with } \\
\text { CMV (mm) }\end{array}$ & $\begin{array}{l}\text { Longest } \\
\text { diameter of } \\
\text { induration } \\
\text { at site of DC } \\
\text { loaded with } \\
\text { KLH (mm) }\end{array}$ & $\begin{array}{l}\text { Longest } \\
\text { diameter of } \\
\text { erythema at } \\
\text { site of DC } \\
\text { loaded with } \\
\text { KLH (mm) }\end{array}$ \\
\hline$\# 1$ & $63 \mathrm{~mm}$ & $64 \mathrm{~mm}$ & $39 \mathrm{~mm}$ & $50 \mathrm{~mm}$ & NA & NA & $6 \mathrm{~mm}$ & $18 \mathrm{~mm}$ \\
\hline$\# 2$ & $35 \mathrm{~mm}$ & $36 \mathrm{~mm}$ & $20 \mathrm{~mm}$ & $25 \mathrm{~mm}$ & NA & NA & $20 \mathrm{~mm}$ & $30 \mathrm{~mm}$ \\
\hline \#3 & $65 \mathrm{~mm}$ & $105 \mathrm{~mm}$ & $70 \mathrm{~mm}$ & $70 \mathrm{~mm}$ & NA & NA & $55 \mathrm{~mm}$ & $135 \mathrm{~mm}$ \\
\hline$\# 4$ & $25 \mathrm{~mm}$ & 80 mm & $45 \mathrm{~mm}$ & $90 \mathrm{~mm}$ & $30 \mathrm{~mm}$ & $80 \mathrm{~mm}$ & $65 \mathrm{~mm}$ & $120 \mathrm{~mm}$ \\
\hline$\# 5$ & $20 \mathrm{~mm}$ & $30 \mathrm{~mm}$ & NA & NA & NR & $20 \mathrm{~mm}$ & NR & $10 \mathrm{~mm}$ \\
\hline$\# 6$ & $20 \mathrm{~mm}$ & $40 \mathrm{~mm}$ & NA & NA & $10 \mathrm{~mm}$ & $20 \mathrm{~mm}$ & $10 \mathrm{~mm}$ & $20 \mathrm{~mm}$ \\
\hline \#7 & NR & NR & NA & NA & NR & NR & NR & NR \\
\hline
\end{tabular}

NR $=$ No reaction at the injection site

$\mathrm{NA}=$ Not available (i.e., immunization not performed with the antigen listed) 

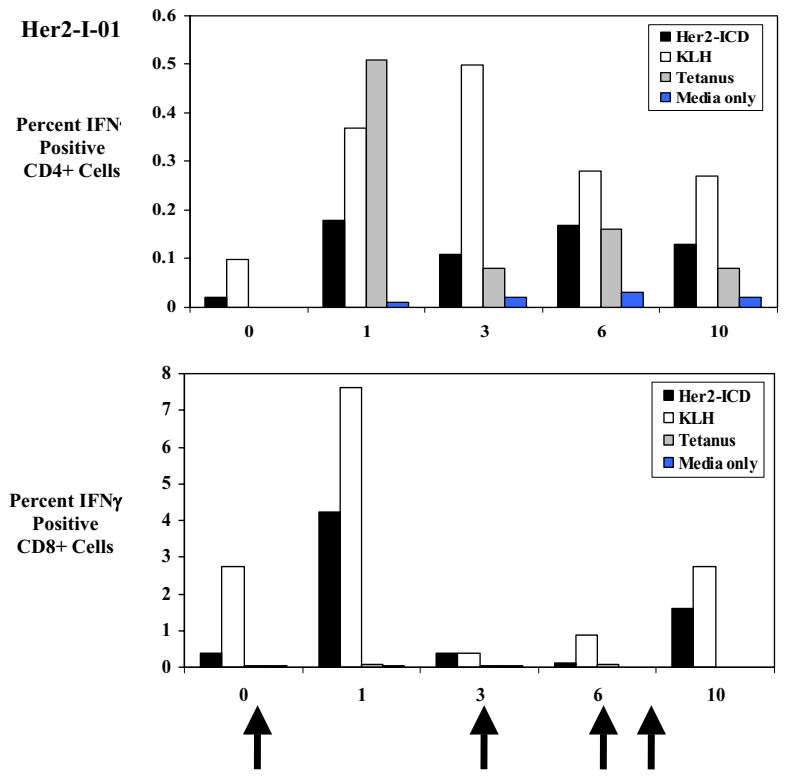

Figure I

Intracellular IFN $\gamma$ production in CD4+ and CD8+ cells in response to HER2-ICD. PBMC from patient Her2-I-0I were stimulated with HER2-ICD (50 $\mu \mathrm{g} / \mathrm{ml}), \mathrm{KLH}$ $(50 \mu \mathrm{g} / \mathrm{ml})$, Tetanus toxoid $(5 \mathrm{Lf} / \mathrm{ml})$ or media alone and analyzed for intracellular IFN $\gamma$ at weeks $0,1,3,6$, and I0. Stimulated cells were fixed, permeabilized and stained with $\alpha$ IFN $\gamma$ FITC, $\alpha$ CD69-PE, $\alpha$ CD8-PerCP and $\alpha$ CD4-APC. The percent of CD4+ and CD8+ T cells that are IFN $\gamma$ and CD69 double positive are represented for each antigen. Cells were gated by forward and side scatter for lymphocytes and positively for CD8 or CD4. Arrows represent when the patient was given each vaccination: week $0,3,6$ and 9 . The $x$-axis represents week of analysis and $y$-axis represents percent CD4+ or CD8+ cells that are CD69+IFN $\gamma+$ in response to each antigen.

demonstrated in figure 2, five of 6 evaluable patients had detectable antibody responses against the ICD with titers exceeding 1:200. There was no obvious correlation with the $\mathrm{T}$ cell responses, although it is of interest that the patient who received the Flt3-Ligand mobilized DC developed the highest titer of anti-ICD antibody response, but had minimal detectable $\mathrm{T}$ cell secretion of interferongamma, suggesting a possible skewing of the $\mathrm{T}$ cell repertoire to a Th2 response.

\section{Clinical Observations}

No acute toxicities were noted during or following any of the four injections. No patient demonstrated an autoimmune response, and no cardiotoxicity, defined as decreased ejection fraction below normal $(<50 \%$ at our institution or decrease of $>10 \%$ from their baseline), was observed on repeat MUGA scans or echocardiograms

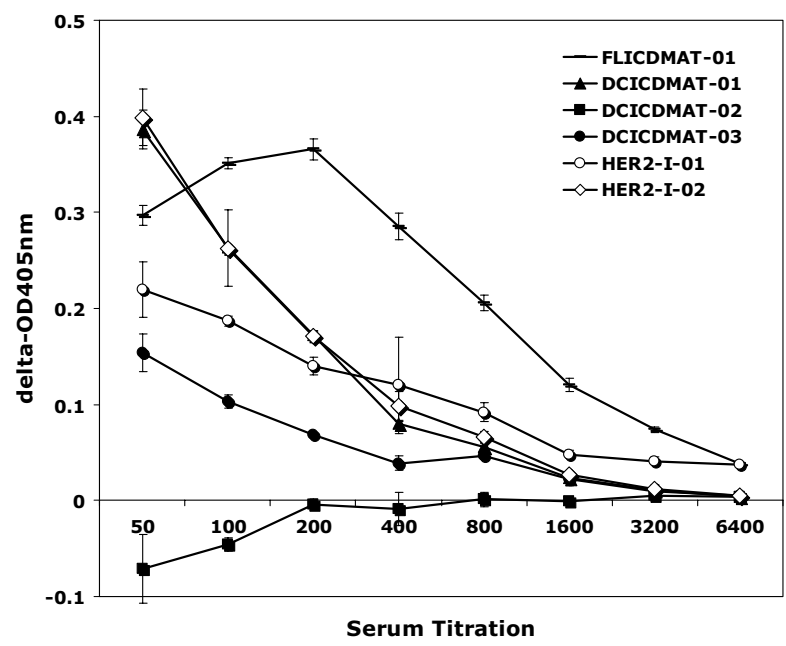

Figure 2

Antibody response to HER2-ICD protein detected by ELISA. High binding 96-well microtiter plates were coated with HER2-ICD protein ( $10 \mu \mathrm{g} / \mathrm{ml}, 200 \mu \mathrm{l} /$ well) for overnight at $4^{\circ} \mathrm{C}$. After washing, and blocking with I\% BSA in PBS for 2 hours, serially diluted patients' sera $(200 \mu \mathrm{l} /$ well $)$ were added to the wells in triplicate and incubated overnight at $4^{\circ} \mathrm{C}$. Control serum from a normal donor was used as a negative control. Alkaline phosphatase conjugated anti-human IgG was added to the plate after washing, and color was developed using p-nitrophenyl phosphate. Absorbance at $405 \mathrm{~nm}$ was measured and the differences from the control serum at each dilution was plotted. The data represents the mean absorbance for each serum dilution \pm standard deviation for each patient depicted.

among the six patients for whom follow-up evaluations were available. In the remaining patient no cardiac events have been reported, and the patient remains fully functional and active. The only patient-reported toxicities were related to prior chemotherapy and/or surgery (e.g., neuropathy and lymphedema, respectively).

Only one of seven patients experienced disease recurrence; she developed a single HER2+ pulmonary lesion nearly 4 years after completing all immunizations and is currently disease-free 9 months post-resection and chemotherapy (Figure 3 ). With a median follow-up of 5.2 years (range:4.6-6.7 years), the DFS rate is $86 \%$ and the overall survival is $100 \%$. The $95 \%$ exact binomial confidence interval for survival at 4.5 years post-immunization is (59\%, 100\%).

\section{Discussion}

Patients with resectable, HER2-expressing breast cancer have a substantial ( $30 \%$ to $>50 \%$ ) risk for recurrence with conventional therapy. Recently, a combined analysis of 


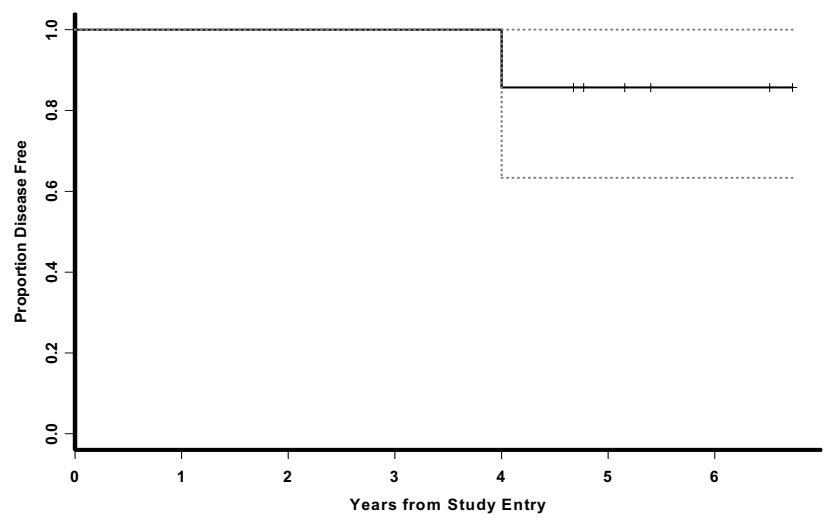

Figure 3

Kaplan-Meier Disease-Free Survival Estimate and $95 \%$ confidence bounds $(n=7)$.

1672 HER2+ patients who were treated with doxorubicin, cyclophosphamide and paclitaxel plus one year of trastuzumab demonstrated a $52 \%$ reduction in the unadjusted risk for disease recurrence and a 33\% reduction in the unadjusted risk for mortality compared to those who did not receive trastuzumab. Four-year disease-free survival (DFS) and OS rates were $85.3 \%$ and $91 \%$, respectively [2]. This required a year of therapy, and as a passive approach, it only provides activity while the drug persists. We hypothesized that a cancer vaccine strategy would provide prolonged efficacy due to T cell immunity, and this report describes the high rate of long term DFS of seven patients with high-risk, resected, HER2 overexpressing breast cancer after immunization with dendritic cell based vaccines loaded with the ICD protein.

Our study is noteworthy for several reasons. First, we were able to generate DCs from PBMCs in all patients despite significant prior chemotherapy. This demonstrates the feasibility of this approach in the post-surgery/post-chemotherapy setting. Notwithstanding, two patients in the group who received matured DCs did not receive all 4 immunizations because the manipulations required to mature and load the DCs with antigen produced significant effects on the number and viability of cells. Three different DC-based preparations were utilized among the seven patients because we were intending to test each for safety in a pilot fashion as we continued to develop more convenient and effective DC vaccines. We realize that the number of different preparations and prior therapies of the patients may limit the ability to make conclusions, but nonetheless, all the patients did have in common immunization with ICD and ECD and prolonged relapse-free survival and 6 of the 7 patients showed development of HER2 specific immune responses. Unfortunately, our ability to continue the study was ultimately limited by the unavailability of clinical grade ICD protein and FLT3-Ligand. The generation of protein-based vaccines is complicated by the complexity of producing stable proteins. Furthermore, there was no evidence that the manipulations required to mature the DC resulted in greater immunogenicity. Neither did the Flt3-ligand mobilized DC approach seem to improve the $\mathrm{T}$ cell responses against the

Table 3: Patient ELISpot response

\begin{tabular}{|c|c|c|c|c|c|}
\hline Patient & Antigen & Pre & Post & Follow up I & Follow up 2 \\
\hline \multirow[t]{2}{*}{ Her2-I-0 I } & $I C D$ & - & - & $+(150)$ & $+(23)$ \\
\hline & ECD & - & $+(23)$ & $+(114)$ & $+(24)$ \\
\hline \multirow[t]{2}{*}{ Her2-I-02 } & $I C D$ & - & $+(22)$ & - & N/A \\
\hline & ECD & - & $\mathrm{N} / \mathrm{A}$ & - & N/A \\
\hline \multirow[t]{2}{*}{ Her2-I-03 } & ICD & - & - & - & $+(23)$ \\
\hline & ECD & $+(49)$ & - & - & $+(23)$ \\
\hline \multirow[t]{2}{*}{ DC-ICD-MAT-0I } & ICD & - & $+(18)$ & N/A & - \\
\hline & ECD & - & - & $\mathrm{N} / \mathrm{A}$ & - \\
\hline \multirow[t]{2}{*}{ DC-ICD-MAT-02 } & $I C D$ & $N / A$ & - & - & - \\
\hline & ECD & N/A & - & - & - \\
\hline \multirow[t]{2}{*}{ DC-ICD-MAT-03 } & $I C D$ & - & N/A & $\mathrm{N} / \mathrm{A}$ & $+(77)$ \\
\hline & ECD & - & $\mathrm{N} / \mathrm{A}$ & $\mathrm{N} / \mathrm{A}$ & $+(129)$ \\
\hline \multirow[t]{2}{*}{ FL-DC-MAT-0I } & $I C D$ & - & - & - & - \\
\hline & ECD & $+(46)$ & - & - & $+(84)$ \\
\hline
\end{tabular}

A positive ELISpot result is represented by + and the number of spots per 100,000 PBMC in parentheses. A positive $(+)$ result is defined as the number of cells secreting IFN $\gamma$ in response to HERr2-ICD or ECD that is at least 10 more than the number of cells secreting IFN $\gamma$ in response to media alone (control cells) and which is statistically greater than the control cells with $p<0.05$.

Each antigen was tested in replicates of 6 for each time point.

Pre represents ELISpot results prior to vaccination, post represents results during or following the vaccination series, and the follow up timepoints represent up to 5 years following the study. 
ICD protein, although it was associated with the highest antibody titer at 5 years of follow-up. Similarly, Disis and colleagues [8] reported that Flt3-Ligand did not activate a HER2-specific proliferative response, although they could detect Her2-specific $\mathrm{T}$ cells responses by ELISPOT. In order to improve upon the immunogenicity of the vaccines used in the current study, we have other strategies in development including heterologous prime-boost strategies using viral vectors and DC-based vaccines modified with viral vectors encoding HER2.

Second, we observed vaccine specific immune responses by DTH in six of seven patients with HER2 ICD protein administered with an ex vivo generated DC. We confirmed that these were HER2 ICD-specific T cell responses in five (two in the mature DC group and three in the immature DC group) of seven immunized patients. At more than 5 years of follow-up, ICD and ECD-specific immune responses were detected by ELISPOT and in some cases, the results were higher than during the immunizations providing tantalizing evidence that the peak response may occur significantly after concluding vaccine therapy. Similar observations have been made in other HER2 vaccine studies. Disis and colleagues demonstrated anti-HER2, Tcell immunity persisting for at least 1 year among 38\% of patients responding to a vaccine derived from potential Thelper epitopes of the HER2/neu protein admixed with granulocyte-macrophage colony-stimulating factor (GMCSF) [7]. In another study by the same group, over half of patients $(n=29)$ enrolled in a dose-escalation study retained HER2/neu specific T-cell immunity after treatment with HER2ICD protein plus GM-CSF vaccine 9 to 12 months after immunization had ended [11]. Interestingly, the rate of immune response seemed to decrease slightly with increasing dose of vaccine $(100 \%$ for low dose, $90 \%$ for intermediate dose, and $78 \%$ for high dose). In some cases, there was a rebound of the $\mathrm{T}$ cell response 2-3 months (or later) after the immunizations were completed. Although efficacy was not reported in this phase I trial, patients with stage II, III and IV HER2 overexpressing breast cancer were enrolled. Also, although we did not have serum remaining from prior to immunization to detect antibody responses, we were encouraged to find detectable antibody responses specific for the ICD protein in 5 of 6 patients at 5 years of follow-up. Although existent antibody responses against HER2 have been detected in non-immunized patients $[20,21]$, the fact that the $\mathrm{Ab}$ response was against the intracellular domain (ICD) suggests that this response could have been activated by the vaccine.

Third, although the number of patients was limited by the eventual unavailability of the ICD protein and FLT3-Ligand, the fact that all seven (100\%) are alive and currently disease-free for up to 6 years following the final vaccina- tion is noteworthy in our opinion. Disis [11] does not report the percentage of patients alive and disease free, but does mention that 2/29 patients relapsed before completing the vaccine series (all were in the low dose cohort). Although two of our patients had also received trastuzumab, one had received it for only 12 weeks; the other has continued on trastuzumab for more than 4 years after completing the immunizations. We are aware that some patients received adjuvant hormonal therapy which could have influenced relapse as well. Larger cohorts of patients must be studied to confirm these results.

Fourth, the immunizations were well tolerated with only grade 1 toxicities reported. Cardiotoxicity due to the immunizations was not reported, despite the fact that two patients had also received trastuzumab and the majority had received prior anthracyclines.

\section{Conclusion}

In this small pilot study, we observed that DC vaccines loaded with HER2 ICD protein are well tolerated, induce DTH, T cell, and antibody responses, and are associated with long term-disease-free survival. It is noteworthy to compare these results with another HER2 directed therapy in which the concept of prolonged immunity and its application to the adjuvant treatment setting was recently explored in patients with resected node positive and node negative breast cancer [13]. A vaccine consisting of a peptide derived from the extracellular domain of HER2 (E75 peptide (HER2 369-377)) mixed with GM-CSF was administered at various doses and schedules. All patients demonstrated in vivo DTH responses and in vitro immunologic responses following vaccination. The recurrence rate for the vaccinated patients was 5.6\% compared to $14.8 \%$ for an observational group of patients at a median of 24 months. These observations are promising and support further study of anti-HER2 vaccine therapy after adjuvant treatment of high-risk, HER2 overexpressing breast cancer. Because trastuzumab is now a standard treatment administered to women with HER2 overexpressing breast cancer as part of adjuvant therapy, and because the safety of trastuzumab plus HER2 targeting vaccines has been preliminarily demonstrated [22], future studies will assess the combination of DC-based HER2 targeting vaccines with trastuzumab.

\section{Competing interests}

The author(s) declare that they have no competing interests.

\section{Authors' contributions}

$\mathrm{MM}$ and $\mathrm{KB}$ carried out clinical trial research.

$\mathrm{AH}$ and TC participated in the writing of the manuscript. 
DN performed statistical analysis.

GD provided expert opinion for the study.

CA and PM were involved in consultation for the trial.

HL was the initiator of the study.

TO developed, performed, and interpretted ELISA assays.

\section{Acknowledgements}

The authors acknowledge the expert assistance provided by Manar Ghanayem and Kirsten Colling in the development, utilization, and interpretation of immunologic testing reported in this article, and to Caron Modeas for expert technical writing assistance.

\section{References}

I. Paik S, Hazan R, Fisher ER, Sass RE, Fisher B, Redmond C, Schlessinger J, Lippman ME, King CR: Pathologic findings from the National Surgical Adjuvant Breast and Bowel Project: prognostic significance of erbB-2 protein overexpression in primary breast cancer. J Clin Oncol 1990, 8:103-I I 2.

2. Romond EH, Perez EA, Bryant J, Suman VJ, Geyer CE Jr., Davidson NE, Tan-Chiu E, Martino S, Paik S, Kaufman PA, Swain SM, Pisansky TM, Fehrenbacher L, Kutteh LA, Vogel VG, Visscher DW, Yothers G, Jenkins RB, Brown AM, Dakhil SR, Mamounas EP, Lingle WL, Klein $\mathrm{PM}$, Ingle JN, Wolmark N: Trastuzumab plus adjuvant chemotherapy for operable HER2-positive breast cancer. $N$ Engl J Med 2005, 353:1673-1684.

3. Emens LA, Reilly RT, Jaffee EM: Breast cancer vaccines: maximizing cancer treatment by tapping into host immunity. Endocr Relat Cancer 2005, I 2: I- I7.

4. Disis ML, Grabstein KH, Sleath PR, Cheever MA: Generation of immunity to the HER-2/neu oncogenic protein in patients with breast and ovarian cancer using a peptide-based vaccine. Clin Cancer Res 1999, 5: I 289-I 297.

5. Disis ML, Schiffman K, Gooley TA, McNeel DG, Rinn K, Knutson KL: Delayed-type hypersensitivity response is a predictor of peripheral blood T-cell immunity after HER-2/neu peptide immunization. Clin Cancer Res 2000, 6: I 347-I 350.

6. Disis ML, Rinn K, Knutson KL, Davis D, Caron D, dela Rosa C, Schiffman K: FIt3 ligand as a vaccine adjuvant in association with HER-2/neu peptide-based vaccines in patients with HER-2/ neu-overexpressing cancers. Blood 2002, 99:2845-2850.

7. Disis ML, Gooley TA, Rinn K, Davis D, Piepkorn M, Cheever MA, Knutson KL, Schiffman K: Generation of T-cell immunity to the HER-2/neu protein after active immunization with HER-2/ neu peptide-based vaccines. J Clin Oncol 2002, 20:2624-2632.

8. Knutson KL, Schiffman K, Cheever MA, Disis ML: Immunization of cancer patients with a HER-2/neu, HLA-A2 peptide, p369377 , results in short-lived peptide-specific immunity. Clin Cancer Res 2002, 8: 1014-1018.

9. Salazar LG, Fikes J, Southwood S, Ishioka G, Knutson KL, Gooley TA, Schiffman K, Disis ML: Immunization of cancer patients with HER-2/neu-derived peptides demonstrating high-affinity binding to multiple class II alleles. Clin Cancer Res 2003, 9:5559-5565.

10. Murray JL, Gillogly ME, Przepiorka D, Brewer H, Ibrahim NK, Booser DJ, Hortobagyi GN, Kudelka AP, Grabstein KH, Cheever MA, loannides CG: Toxicity, immunogenicity, and induction of E75specific tumor-lytic CTLs by HER-2 peptide E75 (369-377) combined with granulocyte macrophage colony-stimulating factor in HLA-A2+ patients with metastatic breast and ovarian cancer. Clin Cancer Res 2002, 8:3407-3418.

II. Disis ML, Schiffman K, Guthrie K, Salazar LG, Knutson KL, Goodell V, dela Rosa C, Cheever MA: Effect of dose on immune response in patients vaccinated with an her-2/neu intracellular domain protein--based vaccine. J Clin Oncol 2004, 22: 1916-1925.

12. Peoples GE, Gurney JM, Hueman MT, Woll MM, Ryan GB, Storrer CE, Fisher C, Shriver CD, loannides CG, Ponniah S: Clinical trial results of a HER2/neu (E75) vaccine to prevent recurrence in high-risk breast cancer patients. I Clin Oncol 2005, 23:7536-7545.

13. Peoples GE, Khoo S, Dehqanzada ZA, Mittendorf EA, Hueman MT, Gurney JM, Woll MM, Ryan GB, Storrer CE, Harris KA, Jama YH, Smith AM, Shriver CD, loannides CG, S. P: Combined clinical trial results of a HER2/neu (E75) vaccine for prevention of recurrence in high-risk breast cancer patients [abstract]. Breast Cancer Research and Treatment 2006, I00, Supplement I:S6.

14. Mellman I, Steinman RM: Dendritic cells: specialized and regulated antigen processing machines. Cell 200I, I 06:255-258.

15. Heath WR, Carbone FR: Cross-presentation, dendritic cells, tolerance and immunity. Annu Rev Immunol 200I, 19:47-64.

16. Dubsky P, Ueno H, Piqueras B, Connolly J, Banchereau J, Palucka AK: Human dendritic cell subsets for vaccination. J Clin Immunol 2005, 25:55I-572.

17. Dees EC, McKinnon KP, Kuhns JJ, Chwastiak KA, Sparks S, Myers M, Collins EJ, Frelinger JA, Van Deventer H, Collichio F, Carey LA, Brecher ME, Graham M, Earp HS, Serody JS: Dendritic cells can be rapidly expanded ex vivo and safely administered in patients with metastatic breast cancer. Cancer Immunol Immunother 2004, 53:777-785.

18. Pulendran B, Banchereau J, Burkeholder S, Kraus E, Guinet E, Chalouni C, Caron D, Maliszewski C, Davoust J, Fay J, Palucka K: Flt3-ligand and granulocyte colony-stimulating factor mobilize distinct human dendritic cell subsets in vivo. J Immunol 2000, 165:566-572.

19. Morse MA, Clay TM, Colling K, Hobeika A, Grabstein K, Cheever MA, Lyerly HK: HER2 dendritic cell vaccines. Clin Breast Cancer 2003, 3 Suppl 4:SI64-72.

20. Disis ML, Pupa SM, Gralow JR, Dittadi R, Menard S, Cheever MA: High-titer HER-2/neu protein-specific antibody can be detected in patients with early-stage breast cancer. J Clin Oncol 1997, 15:3363-3367.

21. Pupa SM, Menard S, Andreola S, Colnaghi MI: Antibody response against the c-erbB-2 oncoprotein in breast carcinoma patients. Cancer Res 1993, 53:5864-5866.

22. Webster DJ, Waisman J, Macleod B, Dela Rosa C, Higgins D, Fintak P, Childs J, Slota M, Salazar LG, Disis ML: A phase I/II study of a HER2/neu (HER2) peptide vaccine plus concurrent trastuzumab [abstract]. Journal of Clinical Oncology 2006, June 20 Supplement:2528.
Publish with Bio Med Central and every scientist can read your work free of charge

"BioMed Central will be the most significant development for disseminating the results of biomedical research in our lifetime. "

Sir Paul Nurse, Cancer Research UK

Your research papers will be:

- available free of charge to the entire biomedical community

- peer reviewed and published immediately upon acceptance

- cited in PubMed and archived on PubMed Central

- yours - you keep the copyright

Submit your manuscript here:

http://www.biomedcentral.com/info/publishing_adv.asp
BioMedcentral 